\title{
Analysis of the incidence and predictive factors of chronic postoperative pain in adult population
}

\section{Yetişkin popülasyonda postoperatif kronik ağrı insidansı ve prediktif faktörlerin analizi}

\author{
Pervin SUTAŞ BOZKURT ${ }^{1}$, Zeki ÖZEN ${ }^{2}$, Elif KARTAL ${ }^{2}$, İkim Ecem EMRE ${ }^{3}$, Çiğdem SELÇUKCAN EROL ${ }^{2}$, \\ Fatma ÖNAY KOÇOĞLU ${ }^{2}$, Gürcan GÜNGÖR ${ }^{1}$, Cem GÜNEYLİ ${ }^{4}$, Gökçen BAŞARANOĞLU ${ }^{5}$, \\ Eser Özlem ÜNLÜSOY ${ }^{1}$, Özlem UĞUR ${ }^{6}$, Sibel BULUÇ BULGEN ${ }^{7}$, on behalf of ASK investigators
}

${ }^{1}$ İstanbul Üniversitesi, Cerrahpaşa Tıp Fakültesi, Anesteziyoloji ve Reanimasyon Anabilim Dalı, İstanbul, Türkiye

${ }^{2}$ İstanbul Üniversitesi, Enformatik Anabilim Dall, İstanbul, Türkiye

${ }^{3}$ Marmara Üniversitesi, İsletme Fakültesi, Almanca İsletme Enformatik Anabilim Dalı, İstanbul, Türkiye

${ }^{4}$ Sağlık Bilimleri Üniversitesi, Tepecik Ĕ̆gitim Araştırma Hastanesi Anesteziyoloji ve Reanimasyon Kliniği, İzmir, Türkiye

${ }^{5}$ Bezm-i Alem Üniversitesi Tip Fakültesi, Anesteziyoloji ve Reanimasyon Anabilim Dall, İstanbul, Türkiye

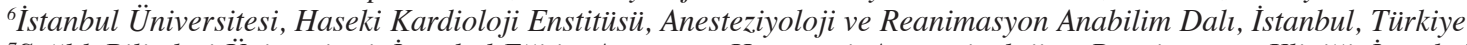

${ }^{7}$ Sağlık Bilimleri Üniversitesi, İstanbul Ĕ̆itim Araştırma Hastanesi, Anesteziyoloji ve Reanimasyon Klini ği, İstanbul, Türkiye

${ }^{8}$ Sa ğllk Bilimleri Üniversitesi, Ümraniye Ĕ̈itim ve Araştırma Hastanesi, Anesteziyoloji ve Reanimasyon Kliniği, İstanbul, Türkiye

(Çalışma yürü̈tüldü̈̆̈̈ sırada yazarların çalıştı̆̆ kurumlar)

\section{ABSTRACT}

\begin{abstract}
Objective: Chronic postoperative pain (CPOP) adversely affects the quality of patients' lives and cause medical and legal problems and economic loss, due to workforce loss. There is no research showing the incidence of CPOP in Turkey. The aim of this study was to find the most prominent factor in the development of CPOP in patients who underwent any kind of surgical procedure.

Method: Patients (165 women and $146 \mathrm{men}$ ) who were operated on in five hospitals were included in the study. A patient data sheet and follow-up form were prepared. All patients were followed up for 2 months by telephone calls and asked about their pain scores. When patients reported pain in 2nd month after their operation, they received re-evaluation and consultation from the pain department.

Results: Sixty-seven patients complained of prolonged pain at the site of surgery 2 months after their surgery, and 46 of these patients $(14.8 \%)$ were diagnosed with CPOP. The presence of CPOP was statistically significant when patients were grouped in age groups of 18-45 years (A) and older than 45 years (B). A statistically significant relationship was found between CPOP diagnosis and ASA scores. According to the results, older age ( $>45$ years) and an ASA score of 3 play major roles in the development of CPOP.

Conclusion: Contrary to previous literature, this study found that factors such as socioeconomic status, type and extent of surgery, geographical region, body mass index, gender, previous experience of pain, drug use and the presence of some neuropathy-related chronic diseases had no effect on the potential development of CPOP. However, ASA scores and age played major roles in the development of CPOP.
\end{abstract}

Keywords: Postoperative chronic pain, age, ASA scores, predictive factors

\section{$\ddot{\mathbf{O Z Z}}$}

Amaç: Ameliyat Sonrası Kronik A ğrı (ASK) hastaların yaşam kalitesine olumsuz etkilerinin yanı sıra tıbbi ve hukuki sorunlara neden olur ve işgücü kaybı nedeniyle ekonomik kayıpları doğurur. Türkiye'de ASK insidansını gösteren herhangi bir araştırma bulunmamaktadır. Bu çalışmanın amacı, her türlü cerrahi girişimden geçecek olan hastaların ASK gelişiminde en belirgin fả ätörü bulmaktir.

Yöntem: Çalışmaya, beş hastanede ameliyat edilen hastalar (165 kadın, 146 erkek) dahil edilmiştir. Hasta veri kayıt ve takip formu hazırlaṇmıştır. Tüm hastalar ağrı skorlarının sorulduğu telefon görüşmeleri ile 2 ay takip edilmiştir. Ikinci ayda hastalardan ağrısı olduğunu bildirenler, ağrı bölümü tarafından yeniden değerlendirmeye alınmıştır.

Bulgular: Altmış yedi olgu, cerrahiden iki ay sonra cerrahi müdahale yapılan bölgede uzun süreli ağrı yakınmasında bulunmuş ve 46 hastada ASK tanısı konulmuştur $(\% 14,8)$. Olgular, 18-45 yaş (A) ve 45 yaşından büyük (B) olarak gruplandırıldığında, ASK'ın varlığı istatistiksel olarak anlamlı bulunmuştur. ASK ve ASA skoru arasında istatistiksel olarak anlamlı ilişki belirlenmiştir. Elde edilen sonuçlara göre, 45 yaş üstü ve ASA skoru 3 olan hastalarda ASK oranı daha yüksektir.

Sonuç: Literatürün aksine, sosyo-ekonomik durum, ameliyat tipi ve derecesi, coğrafi bölge, vücut kitle indeksi, cinsiyet, ağrı ilaçları, sigara/alkol bağımlılı̆̆ı ve bazı nöropati ile ilgili kronik hastalıların varlığı gibi diğer faktörlerin ASK olasılığında etkisi yoktur. Bununla birlikte, ASA ve yaş, ASK olasılığında önemli rol oynamaktadır.

Anahtar kelimeler: Postoperatif kronik ağrı, yaş, ASA skoru, prediktif faktörler
ASK Araştırma Grubunda Diğer Çalışmacılar:

(1) Nilgün ÇOLAKOĞLU

Cem SAYILGAN

Ali Ferit PEKEL

Hasret PİSMIŞ̧OGLU

Ziya SALİHOĞLU

Lale YÜCEYAR

Saffet KARACA

(2) Sevinç GÜLSEÇEN

(4) Gamze ATÇEKEN

(5) Tarı UMUTOĞLU

(6) Pınar KOLUSARI

(7) Yeşim ABUT

Veysel ERDEN

(8) Gülsah KARAÖREN

Nurten BAKAN

Alındığı tarih: 10.01 .2018

Kabul tarihi: 22.05 .2018

Yazışma adresi: Prof. Dr. Pervin Sutaş Bozkurt, Tepecik Eğitim Araştırma Hastanesi Anesteziyoloji ve Reanimasyon, 35180 - İzmir - Türkiye e-mail: apervin@yahoo.com 


\section{INTRODUCTION}

Chronic postoperative pain (CPOP) is defined as pain that occurs after a surgical procedure and persists more than 2 months after surgery. The duration of pain varies widely, from several months to several years. The prevalence rates of mild-to-moderate and also chronic CPOP vary between $10 \%$ and $50 \%$, and $2 \%$ and $10 \%$, respectively ${ }^{(1)}$. Other causes of the pain, such as chronic infection, pre-existing problems or malignancy, should be excluded when diagnosing $\mathrm{CPOP}^{(2)}$.

Psychological, social and economic factors play an important role in the occurrence of CPOP ${ }^{(3)}$. Genetic differences also influence expression of pain. Multiple surgical procedures lead to a high incidence of CPOP. Some specific types of surgery, such as thoracotomy, cardiac surgery, inguinal hernia repair, breast cancer surgery and limb amputation, are associated with severe CPOP with incidence rates of $\mathrm{CPOP}$ as 5\%-65\%, 30\%-50\%, 5\%-63\%, $11 \%-57 \%$ and $30 \%-80 \%$, respectively ${ }^{(4)}$. Surgical factors, such as duration, and technique of the operation, site and type of incision, surgeon's experience and surgical centre, are also related to the incidence of $\mathrm{CPOP}^{(5)}$.

According to a Turkish Ministry of Health statistical report, 4,798,996 operations were performed in all the health institutions in Turkey during $2014{ }^{(6)}$. Assuming that the incidence of CPOP in the country is the same or similar to the incidence in other countries (lowest incidence is 5\%), CPOP should have occurred in approximately 240,000 cases in 2014 .

The aim of this study was to determine the factors that affect the development of CPOP in adult patients in Turkey who planned to undergo elective surgery.

\section{MATERIALS and METHODS}

This prospective longitudinal study was approved by the Institutional Ethics Committee, and written consents were obtained from the participating hospitals and patients before entry into the study. Patients who were unable to express themselves, or whose understanding of the mother language was insufficient, were excluded.

A data sheet was prepared by the study team after an evaluation of international literature on factors related to CPOP, taking into account Turkey's population with unique genetic, social and demographic characteristics. Data on 311 patients were collected from five hospitals in two major cities in Turkey (Istanbul and Izmir), where it is thought that patients represent the whole country due to the huge mobility of patients within the country. The institutions that contributed to the study were Istanbul University Cerrahpaşa Medical Faculty and Cardiology Institution, Izmir Tepecik Training and Research Hospital, Istanbul Training and Research Hospital and Bezmialem University Medical Faculty (Istanbul). Outpatients or inpatients over the age of 18 years who underwent elective surgery for any indication (ear, nose and throat, gynaecology, general surgery, cardiovascular surgery, orthopedics, ophthalmology, urology, thoracic surgery and neurosurgery and obstetrics and gynaecology clinics) and who were operated under sedo-analgesia and/or regional anaesthesia (RA) and/or general anaesthesia (GA) were included. All anaesthesiologists were free to perform their own method of anaesthesia, analgesia and acute postoperative pain treatment strategy. During the preoperative visit, the Numeric Rating Scale (NRS) was explained to patients, whose preoperative pain status was evaluated. The data sheet included demographic information, such as birth place, the family history , social and economic status, general health, previous surgeries, chronic illnesses, pain status and substance use. Relevant data were recorded on the sheet by the attending anaesthesiologist. Each patient's pain status was followed up for 2 months through telephone calls made by the study team (study member other than attending anaesthesiologist). Patients were asked about their NRS scores and the presence of hypoesthesia/hyperesthesia every other 2 weeks (on the $15^{\text {th }}$, $30^{\text {th }}, 45^{\text {th }}$ and $60^{\text {th }}$ day after the surgery). They were asked to rate their maximum pain intensity felt at the 
surgical site using an NRS score of 0-10, where 0 indicates no pain and 10 indicates the most severe pain. These data were also recorded on the data sheet. The patients who reported pain in the second month, were revisited and received pain consultation. Complaints about pain were evaluated for complications and/or exacerbation of disease, and pain treatment was planned and applied. Based on the NRS scores, CPOP was grouped into three severity levels as no pain ( $\mathrm{NRS}=0)$, mild- moderate pain $(\mathrm{NRS}=1-6)$ and severe pain (NRS=7-10).

The data entry platform was prepared using PHP language based on the patient data sheets, and the data were stored on a MySQL database. To understand the data set, descriptive statistical analyses were performed, and graphics were used to visualise the trends in the data. SPSS for Windows Version 22 and Microsoft Excel 2016 were used to perform a chisquare test to determine the factors that affect CPOP.

\section{RESULTS}

The gender distribution of the sample was fairly even. Indeed, 146 (47\%) patients were men and 165 patients were women (53\%). The patients' ages ranged from 18 to $83(46.2 \pm 15.48)$ years. One hundred, and fifty-three patients (49.2\%) were between 18 and 45 years of age and 158 patients $(50.8 \%)$ were older than 45 years.

Seventy-eight percent of 311 patients had no pain, the remaining patients had mild $(16 \%)$, moderate

Table 1. Pain severity at the end of the 2-month post-surgery period.

\begin{tabular}{lcccc}
\hline Pain status & $\begin{array}{c}\text { Mild } \\
\%(\mathbf{n})\end{array}$ & $\begin{array}{c}\text { Moderate } \\
\%(\mathbf{n})\end{array}$ & $\begin{array}{c}\text { Severe \% } \\
(\mathbf{n})\end{array}$ & $\begin{array}{c}\text { Grand } \\
\text { total (n) }\end{array}$ \\
\hline CPOP & $71.4(35)$ & $53.3(8)$ & $100(3)$ & $(46)$ \\
Women & 17 & 4 & 3 & 24 \\
Men & 18 & 4 & 0 & 22 \\
Relapse & $16.3(8)$ & $13.3(2)$ & $0(0)$ & $(10)$ \\
Infection & $6.1(3)$ & $0(0)$ & $0(0)$ & $(3)$ \\
Complication & $0(0)$ & $20(3)$ & $0(0)$ & $(3)$ \\
Reoperation & $4.1(2)$ & $6.7(1)$ & $0(0)$ & $(3)$ \\
Malignancy & $6.7(1)$ & $6.7(1)$ & $0(0)$ & $(2)$ \\
Grand total \% (n) & $100(49)$ & $100(15)$ & $100(3)$ & $(67)$ \\
& & & & \\
\hline
\end{tabular}

CPOP; Chronic Postoperative Pain
$(5 \%)$, and severe (1\%) pain. Only 67 patients $(22 \%)$ reported pain felt on the surgical site and $15 \%(n=46)$ of these patients were diagnosed with CPOP. The other reasons for pain during the second month were relapse of the disease (which indicated a need for additional surgery), complications, malignity and reoperation. The distribution of the presence of CPOP and other reasons of pain, pain severity scores and gender, are presented in Table 1.

When patients were grouped in age groups of 18-45 years (A) and older (B), the incidence rates of CPOP were $10.5 \%$ and $19.6 \%$, respectively $(\mathrm{p}=0.046$; Table 2). The incidence of CPOP increased in patients older than 45 years. Twenty-seven patients had ASA 3 scores from which one or combination of problems listed below were responsible (chronic obstructive lung disease, diabetes, cardiac diseases, chronic renal diseases, obstructive apnea, and Parkinson disease). A statistically significant difference was found between ASA scores and pain status after performing the chi-square test $(\mathrm{p}=0.001 ;<0.05)$. The rate of CPOP was higher for patients who had an ASA score of 3 .

The body mass indices (BMI) of the patients were calculated based on their heights and weights. According to this criterion, the respective percentages of the patients were cachectic (BMI <18.5) (5.1\%), normal $(37.3 \%)$, and obese (BMI >25) $(57.6 \%)$.

Patients' pain status according to their BMIs were as follows: $93.8 \%$ of the cachectic, $75 \%$ and $79.3 \%$ of normal and obese patients did not experience any

Table 2. Relationships among age groups, ASA scores and detailed pain status.

\begin{tabular}{|c|c|c|c|c|c|c|}
\hline & & \multicolumn{3}{|c|}{ Pain status } & \multirow[b]{2}{*}{$\begin{array}{c}\text { Total } \\
\text { (n) }\end{array}$} & \multirow{2}{*}{ 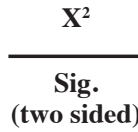 } \\
\hline & & $\begin{array}{l}\text { No pain } \\
\text { (n) }\end{array}$ & $\begin{array}{l}\text { Other } \\
\text { (n) }\end{array}$ & $\begin{array}{c}\text { CPOP } \\
\text { (n) }\end{array}$ & & \\
\hline \multirow[t]{2}{*}{ Age } & $18-45$ years & 129 & 8 & 16 & 153 & \multirow[b]{2}{*}{0.046} \\
\hline & $>45$ years & 115 & 13 & 30 & 158 & \\
\hline \multirow[t]{3}{*}{ ASA score } & ASA 1 & 137 & 8 & 21 & 166 & \multirow{4}{*}{0.001} \\
\hline & ASA 2 & 94 & 10 & 14 & 118 & \\
\hline & ASA 3 & 13 & 3 & 11 & 27 & \\
\hline Total & & 244 & 21 & 46 & 311 & \\
\hline
\end{tabular}

CPOP; Chronic Postoperative Pain, $X^{2}$ Chi-square 
pain. The evaluation of this data by chi-square test revealed that there is no relation between BMI and pain status $(p=0.629)$.

As seen in the distribution of patients according to their surgery clinics (Table 3), most patients received operations in ear, nose and throat, gynaecology and general surgery clinics. Moreover, $72 \%$ of the patients stayed at least one night in the hospital and the rest had undergone day case surgery. More than half of the patients (55\%) underwent major surgery (eg;coronary artery bypass grafting-CABG, lobectomy of the lung, radical neck dissection, laryngectomy, mastectomy with lymph node dissection, open cholecystectomy, hysterectomy, C-Section, intracranial surgery, resection of prostate, kidney, laminectomy, total femoral or knee replacement, hemicolectomy, pancreatectomy, sleeve gastrectomy, enucleation of the eye, total cystectomy and augmentation, brain tumor resection etc) and $21 \%$ of these were extensive nature (CABG, lobectomy of the lung, total laryngectomy etc.) ${ }^{(7)}$. Minor surgery such as septoplaty, rhinoplasty, middle ear surgery, thyroidectomy, mastectomy, inguinal hernia repair, laparoscopic cholecystectomy, hemorhoidectomy, curettage, diagnostic hysteroscopy, lumbar discectomy, cataract and several ophtalmological procedures, arthroscopic surgery, mammoplasty, cystectomy, vasectomy, circumcision, varicosectomy and likewise performed in $45 \%$ of the patients ${ }^{(7)}$. There was no relationship between CPOP and the patients' geographical regions of birth place $(\mathrm{p}=0.695 ;>0.05$; Table 3$)$.

A statistically significant difference was found between socio-economic status and pain status $(\mathrm{p}=0.005 ;<0.05)$. As socio-economic status (as defined by the patient) decreased, the presence of moderate and severe pain increased. However, this statistically significant difference was lost in patients with the diagnosis of CPOP ( $\mathrm{p}=0.057 ;<0.05$; Table 4$)$.

When the presence of systemic diseases was evaluated, it was found that $20.3 \%$ of patients had not systemic diseases and $23 \%$ of patients with systemic disease had mild, moderate or severe pain. Almost half of the patients $(n=158)$ were not taking any medications. Forty-three patients who were not under continuous medication had mild-to-severe pain.

Table 3. Distribution of patients according to their clinic and region of Turkey.

\begin{tabular}{|c|c|c|c|c|c|c|}
\hline \multirow[b]{2}{*}{ Clinic } & \multirow[b]{2}{*}{$\mathbf{n}$} & \multirow[b]{2}{*}{$\%$} & \multirow[b]{2}{*}{ Region of Turkey } & \multicolumn{2}{|c|}{$\begin{array}{c}\text { Chronic } \\
\text { postoperative } \\
\text { pain }\end{array}$} & \multirow[b]{2}{*}{ Total } \\
\hline & & & & No pain & Pain & \\
\hline Ear, nose and throat & 74 & 23,8 & Mediterranean & 3 & 7 & 10 \\
\hline $\begin{array}{l}\text { Obstetrics and } \\
\text { gynaecology }\end{array}$ & 61 & 19,6 & East Anatolian & 9 & 40 & 49 \\
\hline General surgery & 55 & 17,7 & Aegean & 4 & 25 & 29 \\
\hline $\begin{array}{l}\text { Cardiothoracic } \\
\text { surgery }\end{array}$ & 41 & 13,2 & $\begin{array}{l}\text { South East } \\
\text { Anatolian }\end{array}$ & 3 & 26 & 29 \\
\hline Orthopaedics & 32 & 10,3 & Middle Anatolian & 7 & 29 & 36 \\
\hline Ophthalmology & 24 & 7,7 & Black Sea region & 12 & 70 & 82 \\
\hline Urology & 20 & 6,4 & Marmara region & 7 & 54 & 61 \\
\hline Neurosurgery & 4 & 1,3 & Foreigners & 1 & 14 & 15 \\
\hline
\end{tabular}

Table 4. Pain status according to patients' socio-economic status.

\begin{tabular}{|c|c|c|c|c|c|}
\hline & & \multicolumn{2}{|c|}{ All pain types } & \multirow[b]{2}{*}{ Total } & \multirow{2}{*}{ Sig. (two sided) } \\
\hline & & No & Yes & & \\
\hline \multirow{5}{*}{$\begin{array}{l}\text { Socio-economic } \\
\text { status } \\
\text { Total }\end{array}$} & Low & 137 & 43 & 180 & \multirow[t]{5}{*}{0.005} \\
\hline & High & 107 & 24 & 131 & \\
\hline & & 244 & 67 & 311 & \\
\hline & & \multicolumn{2}{|c|}{$\begin{array}{c}\text { Chronic } \\
\text { postoperative } \\
\text { pain }\end{array}$} & \multirow[b]{2}{*}{ Total } & \\
\hline & & No & Yes & & \\
\hline \multirow{3}{*}{$\begin{array}{l}\text { Socio-economic } \\
\text { status } \\
\text { Total }\end{array}$} & Low & 147 & 33 & 180 & \multirow[t]{3}{*}{0.057} \\
\hline & High & 118 & 13 & 131 & \\
\hline & & 265 & 46 & 311 & \\
\hline
\end{tabular}

\section{DISCUSSION}

As mentioned in the introduction section, there have been no studies on the overall incidence of CPOP in our country. Considering the population of Turkey and annual number of surgeries, this study is considered very important and unique. The vast majority of the patients $(78.5 \%)$ who participated in the study had no pain and $85 \%$ of the patients did not experience CPOP. Most patients who experienced pain during the follow-up period were diagnosed with CPOP at the end of the second month (67 of 46; $68.7 \%$ ). In our sample, we observed that the incidence of CPOP in Turkey was $14.8 \%$ when all types of 
surgeries were included.

Turan et al. ${ }^{(8)}$ reported a pain incidence of $39.2 \%$ in 240 patients 3 months after breast surgery. In our study where patients with fairly even gender distribution underwent various types of surgery, the incidence of chronic pain was far lower (15\%) than reported by Turan et al. for their study group . In Turan et al.'s study, there was a high correlation between CPOP and axillary dissection compared with sole mastectomies. The female population in our study consisted mainly of obstetrics and gynaecology patients.

According to most of the literature reports, CPOP decreases as age increases. Cregg et al. ${ }^{(3)}$ summarised the findings of 15 studies, reporting that younger age is associated with a higher rate of CPOP. A 5\% reduction in the probability of developing chronic pain with every year of increasing age was reported ${ }^{(9)}$. Smith et al. ${ }^{(10,11)}$ determined rates of postmastectomy CPOP in different age groups as $65 \%, 40 \%$, and $26 \%$ in patient groups of $30-49,50-69$, and $>70$ years of age, respectively. All of these incidence rates are much higher than ours. Contrary to all of these literature data, in our series age also plays a major role in the development of CPOP, and as age increases, the probability of chronic pain also increases. Sipila et al. ${ }^{(12)}$ and Turan et al. ${ }^{(8)}$ had similar results, namely they found a significant linear correlation between CPOP and age. Discrepancies between studies may depend on the type end extent of the operations, genetic characteristics and age of the populations, and socio-cultural differences that affect the expectations of the patients.

Similar to the results of Gerbershagen et al. ${ }^{(13)}$ and reviews of CPOP, in our study, there was a correlation between ASA scores and the occurrence of CPOP. Patients who had chronic multi-systemic diseases had a higher incidence of CPOP.

Studies that have evaluated the incidence of BMI and CPOP have reported a positive correlation between them, ${ }^{(8,12,14)}$ which has been attributed to difficulties encountered during the surgical procedures performed in obese patients. Recently, it has been reported that some obese patients display hypoalge- sia to noxious electrical stimuli ${ }^{(15)}$. The results of our study showed that BMI has no effect on postoperative chronic or other types of pain formation.

Daly et al. ${ }^{(16)}$ reported that socio-economic status influenced post-caesarean section pain in a study group of 205 women from a predominantly socially deprived population in the United Kingdom, all of whom received acute postoperative pain treatment of a standard quality. The authors decided that lower socio-economic status resulted in a higher incidence of chronic pain ${ }^{(16)}$. In our study group, there was an inverse relationship between patients' socio-economic status and pain status, and patients underestimate pain intensity as their socio-economic situation improved although this relationship was not statistically significant for patients diagnosed with CPOP. These findings are consistent with the results from the general population; that there are significant relationships between pain and lower socio-economic status with respect to the incidence of general pain ${ }^{(17)}$.

Various reports have stated that various operations, such as amputations and thoracic, breast cancer and obstetrical surgeries, are associated with higher incidences of $\mathrm{CPOP}{ }^{(4,11,17)}$. Operation types were distributed evenly in our group of patients, and laparoscopic techniques were frequently applied. It is thought that lack of any relationship between surgery type and pain was related to this even distribution of genders.

A study performed in our country to determine the prevalence of chronic pain found that chronic pain is more common in the Western and Middle Anatolian regions of Turkey, urban areas, patients in the 35-44 years age group and female patients $(\mathrm{p}<0.001)^{(18)}$. In our study, we investigated people admitted from various districts into major referral hospitals in the country, and couldn't find any correlation between the geographical region and occurrence of CPOP.

In our study group, the use of analgesics and antipsychotics and previous experience of chronic pain syndromes and surgery had no effect on the development of CPOP, unlike the findings of several studies in the literature ${ }^{(13)}$. 
In conclusion, age and ASA status had an effect on the development of CPOP. Contrary to the findings of other studies, factors such as socio-economic status, type and extent of the operation, geographical region, BMI, gender, previous experience of pain, drug use and the presence of some neuropathy-related chronic diseases had no effect the development of CPOP. The inconsistency of our findings with those of other studies may be due to the low incidence of CPOP in this study, which disables statistical evaluation and hides the coincidences.

\section{Acknowledgements}

This work was supported by Scientific Research Projects Coordination Unit of Istanbul University (Project number: 23467).

\section{REFERENCES}

1. Hoofwijk DM, Fiddelers AA, Peters ML, et al. Prevalence and predictive factors of chronic postsurgical pain and poor global recovery 1 year after outpatient surgery. Clin J Pain. 2015;31:1017-25. https://doi.org/10.1097/AJP.0000000000000207

2. Macrae WA. Chronic post-surgical pain: 10 years on. Br J Anaesth. 2008;101:77-86. https://doi.org/10.1093/bja/aen099

3. Cregg R, Anwar S, Farquhar-Smith P. Persistent postsurgical pain. Curr Opin Support Palliat Care. 2013;7:144-52. https://doi.org/10.1097/SPC.0b013e328360b09e

4. Simanski CJ, Althaus A, Hoederath S, et al. Incidence of chronic postsurgical pain (CPSP) after general surgery. Pain Med. 2014; 15:1222-9. https://doi.org/10.1111/pme.12434

5. Akkaya T, Ozkan D. Chronic post-surgical pain. Agri. 2009;21:1-9.

6. Ministry of Health, General Directorate of Health Research, "Republic of Turkey Ministry of Health, Health Statistics Yearbook 2014" 2014. (Internet). Available from: http://eku- tuphane.sagem.gov.tr/kitaplar/saglik_istatistikleri_ yilligi_2014.pdf. (Accessed: 7-Aug-2017)

7. The Winnipeg Regional Health Authority (WRHA). (Internet) http://wrha.mb.ca/extranet/eipt/files/EIPT-003-002.pdf (Revised: 2016.07.06)

8. Turan M, Karaman Y, Tekgul ZT, Karaman S, Uyar M, Gonullu M. Incidence and risk factors of chronic postoperative pain after breast surgery. Tepecik Eğit ve Araşt Hast Dergisi. 2016;26:207-14.

9. Poleshuck EL, Katz J, Andrus CH, et al. Risk factors for chronic pain following breast cancer surgery: a prospective study. J Pain. 2006;7:626-34. https://doi.org/10.1016/j.jpain.2006.02.007

10. Smith WC, Bourne D, Squair J, Phillips DO, Chambers WA. A retrospective cohort study of post mastectomy pain syndrome. Pain. 1999;83:91-5. https://doi.org/10.1016/S0304-3959(99)00076-7

11. Johansen A, Romundstad L, Nielsen CS, Schirmer H, Stubhaug A. Persistent postsurgical pain in a general population: Prevalence and predictors in the Troms $\emptyset$ study. Pain. 2012; 153:1390-6. https://doi.org/10.1016/j.pain.2012.02.018

12. Sipilä R, Estlander A, Tasmuth T, Kataja M, Kalso E. Development of a screening instrument for risk factors of persistent pain after breast cancer surgery. $\mathrm{Br} \mathrm{J}$ Cancer. 2012;107:1459-66. https://doi.org/10.1038/bjc.2012.445

13. Gerbershagen HJ, Ozgur E, Dagtekin O, et al. Preoperative pain as a risk factor for chronic post-surgical pain - Six month follow-up after radical prostatectomy. Eur J Pain. 2009;13:1054-61. https://doi.org/10.1016/j.ejpain.2008.11.020

14. Kärki A, Simonen R, Mälkiä E, Selfe J. Impairments, activity limitations and participation restrictions 6 and 12 months after breast cancer operation. J Rehabil Med. 2005;37:180-8.

15. Torensma B, Oudejans L, van Velzen M, Swank D, Niesters M, Dahan A. Pain sensitivity and pain scoring in patients with morbid obesity. Surg Obes Relat Dis. 2017;13:788-95. https://doi.org/10.1016/j.soard.2017.01.015

16. Daly B, Young S, Marla R, et al. Persistent pain after caesarean section and its association with maternal anxiety and socioeconomic background. Int J Obstet Anesth. 2017;29:57-63. https://doi.org/10.1016/j.ijoa.2016.10.004

17. Morgan CL, Conway P, Currie CJ. The relationship between self-reported pain and measures of socio-economic disadvantage. Eur J Pain. 2011 Nov; 15:1107-11. https://doi.org/10.1016/j.ejpain.2011.04.010

18. Erdine S, Hamzaoglu O, Ozkan O, Balta E, Domac M. Türkiye'de erişkinlerin ağrı prevelansı. Ağrı. 2001;13(2):22-30. 